\title{
Some Aspects of an Inversion Layer over the Japan Sea under a Winter Monsoon Situation as Revealed by Dropsonde and Aerial Photographic Observation
}

\author{
by \\ S. Matsumoto and K. Ninomiya \\ Meteorological Research Institute, Tokyo \\ (Received July 23, 1966)
}

\begin{abstract}
A remarkable inversion layer was observed over the Japan Sea under a winter monsoon situation on Jan. 30, 1965. Detailed analysis on the structure of this inversion layer and on the behavior of the cumulus convection in the sub-inversion layer is made by using the data of dropsonde and aerial photographic observations.

It is found that the convective clouds exist only in sub-inversion layer and no evidence of air mass modification is observed above the inversion. Also a high correlation between the mesoscale undulation of the inversion layer and the groups of active convections is analysed.
\end{abstract}

\section{Introduction}

Several studies based on the synthetic observations, which had been carried out by the Heavy Snow Storm Research Project since 1963, clarified some aspects concerning the winter monsoon and the cumulus activity over the Japan Sea (MATSUмото et al, 1963 and 1965, Matsumoto and NinomiYa, 1965 and 1966, Ninomiya, 1966 and AsAI, 1966).

As a characteristic feature of the winter monsoon, a remarkable inversion layer is observed in the polar air mass over the Japan Sea and her neighbourhood. Pioneering observations there had already been made more than 25 years before by radio sonde (Arakawa et al, 1939) and by air plane (AgEmatsu, 1940). This inversion works as a lid on the cumulus convection and, therefore, the cumulus develops usually in the layer under the inversion base only. The height of the inversion base varies according to the synoptic situation, i.e., it rises when a cut-off cold vortex passes over the Japan Sea, and it is rather lower in the case of the usual cold air outbreak.

After the extratropical cyclone which was located to the south of the Japan Islands on Jan. 29 moved over the north-eastern Pacific, a cold air outbreak took place on Jan. 30, 1965. Dropsonde observation and aerial photographic observation 
of cloud were carried out by the Heavy Snow Storm Research Project over the Japan Sea coastal area of the Hokuriku District. A Beachcraft Queen Air 80 was chartered for the observation flight, and dropsondes were released at $6000 \mathrm{~m}$ above sea level. The cloud photographs were taken at every $30 \mathrm{sec}$. interval by $35 \mathrm{~mm}$ cameras with super-wide angle lenses $(f=21 \mathrm{~mm})$ which were mounted at the windows on both sides of the aircraft.

In this paper, some aspects of the inversion layer and the cumulus activity underneath are to be analysed by using the data of observation mentioned above. Also some considerations on the long-wave radiation balance of the inversion layer and on the momentum mixing in the convective layer are to be made.

\section{The synoptic situation of the inversion layer}

It would be necessary to begin with a description of the synoptic situation. The surface weather map at 09 LMT, Jan. 30, 1965 is shown in Fig. 1. A well developed extratropical cyclone is located over the Kamchatka Peninsula. The cold air outbreak begins to set forth right after the other cyclone, which has passed along the southern coast of the Japan Islands, moves further east. The strong gradient of temperature and the wind perpendicular to the isotherms, which are seen on $850 \mathrm{mb}$ chart given in Fig. 2, lead us to infer a remarkable modification of the air mass. Actually, predominant convective clouds are observed over the Japan Sea coastal area.

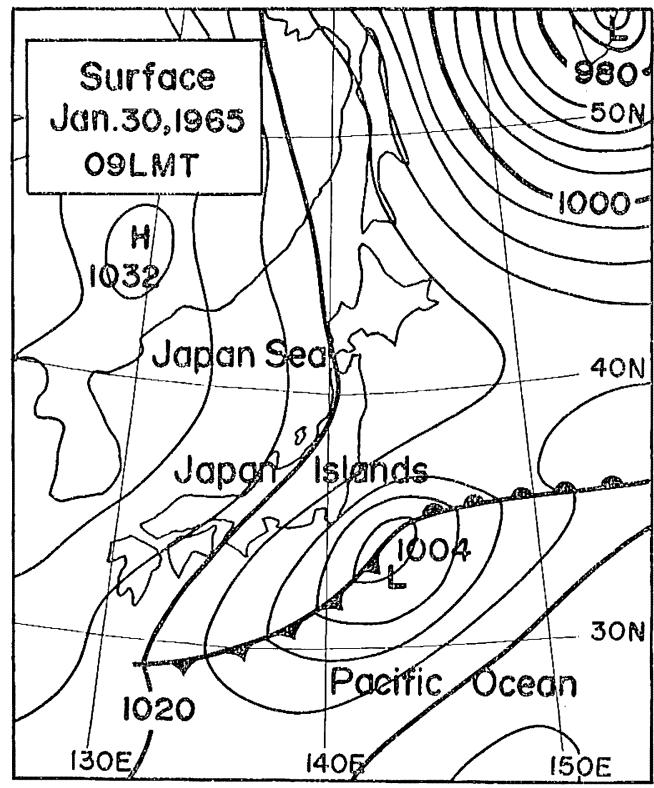

Fig. 1. The surface weather map at 09 L.M.T., Jan. 30, 1965.

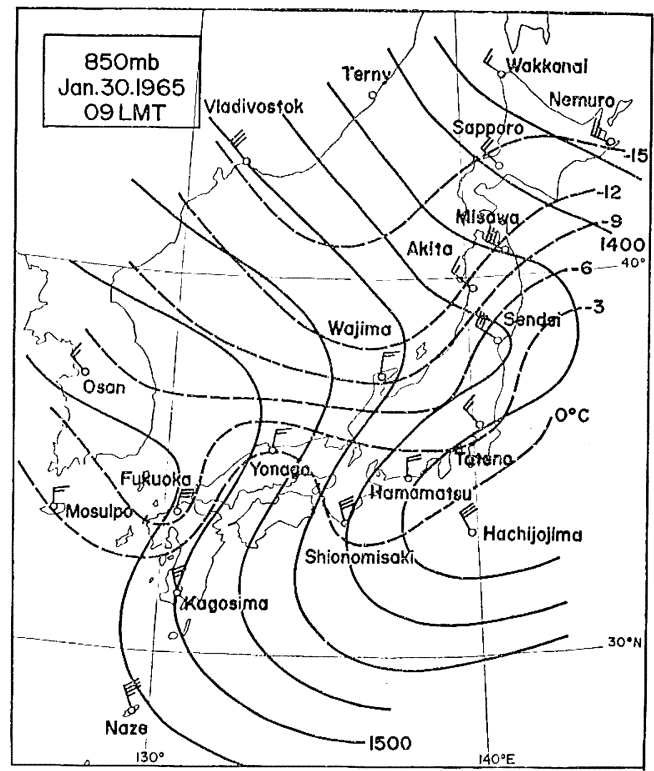

Fig. 2. The $850 \mathrm{mb}$ weather map at 09 L.M.T., Jan. 30, 1965.

A remarkable inversion layer is observed in the lower troposphere over the Japan Sea and a front is located to the south of the Japan Islands as seen in the vertical cross 
section along the $140^{\circ} \mathrm{E}$ meridian, Fig. 3. Although it looks as if the inversion layer extends to the frontal layer, the difference on the humidity distribution above these layers is very definite. Concerning the inversion, the moist air is found only under the inversion base and the humidity decreases rapidly above it, while a deep moist layer extending up to higher than $600 \mathrm{mb}$ level is observed above the frontal layer over the Pacific coastal area. It would be concluded, therefore, that the inversion layer is not the northern extension of the polar front but another system which develops in the polar air mass overflowing from the polar continent.

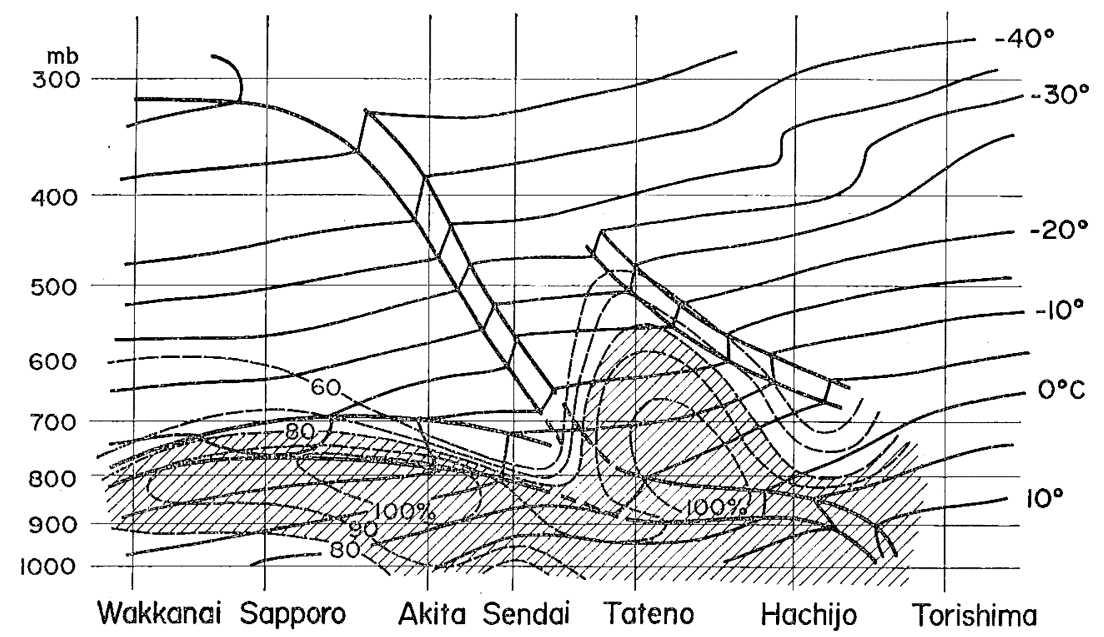

Fig. 3. The vertical cross section along $140^{\circ} \mathrm{E}$ meridian. The heavy solid line, the solid line and the broken line are the boundary of front or inversion, the isotherm and the isoline of humidity, respectively. The moist area in which humidity is higher than $80 \%$ is shown by hatches.

The characteristic features of the inversion are well understood by looking at the ascent curves of the radiosonde observation at the stations around the Japan Sea

Fig. 4a. The ascent curves (the solid $\rightarrow$ and the broken line are the temperature and dew-point temperature respectively) observed over the continent, i. e. Terny (31909): Vladivostock (31960) and Osan (47122).

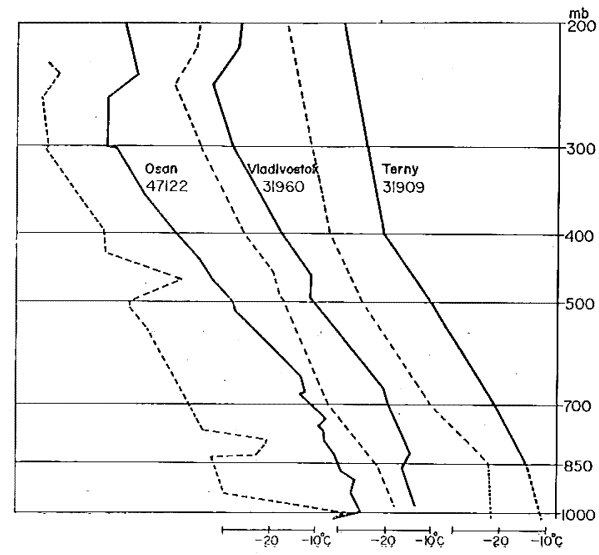




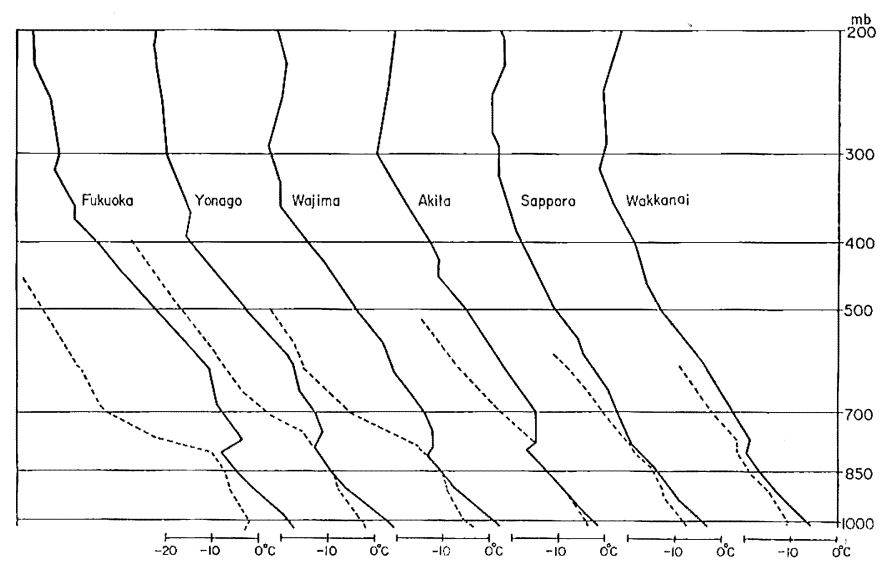

Fig. 4b. Same as in Fig. 4a, but over the Japan Islands.

(Fig. 4). The decrease of humidity above the inversion is observed at each station (see also Arakawa et al, 1939). It is noticed, however, that the rate of decrease is more remarkable at the southern stations. It is reported (SeKrgucni, 1965) that the response time of the hair hygrometer becomes longer when the air temperature decreases and the measurement of humidity at temperatures under $-10^{\circ} \mathrm{C}$ is seriously liable to error. Thus it may be said that the humidity at the northern stations might be lower than that shown in Fig. 4. Next, the lapse rate in the sub-inversion layer is to be mentioned. The dry adiabatic and the wet adiabatic lapse rate are observed in the sub-cloud layer and in the cloud layer respectively. In other words, it could be said that the equivalent potential temperature is homogeneous in the convective layer. Mryazawa (1949) also analyzed the inversion layer when the winter monsoon predominated, and found out that a heavy snowfall occurred over the mountainous area of the Hokuriku District when the height of the inversion base was $2500 \sim 3000 \mathrm{~m}$.

Similar situations of the vertical temperature and moisture distribution associated with an inversion layer have been analysed in the tropical maritime region by several authors (Bunker et al, 1949, RieHl et al, 1951 and Malkus, 1958).

The vertical cross section along the Japan Sea coastal line is presented in Fig. 5. Although the inversion extends almost horizontally over the Japan Sea, some undulation is observed. The highest inversion base is located over Sapporo at 09 LMT Jan. 30 and over Wajima at 21 LMT Jan. 29 respectively. The position of the highest inversion seems to move together with the area of strong wind. This fact implies that the inversion rises where the supply from the underlying sea surface is large. This hypothesis, however, is yet to be verified by a number of case studies.

Another notable fact is that the mixing ratio of water vapour at the top of the inversion is very uniform over the whole Japan Sea area, i.e. $0.7-0.9 \mathrm{gr}^{\circ} \mathrm{kgr}^{-1}$. (This value should be reduced to $0.4-0.9 \mathrm{gr} \cdot \mathrm{kgr}^{-1}$, if the overestimation of the humidity at the northern stations, mentioned previously, is considered). As the polar continental air mass overflows over the relatively warm sea surface, the modification begins at the lower part of the air mass. The heat and moisture supplied from the sea surface 


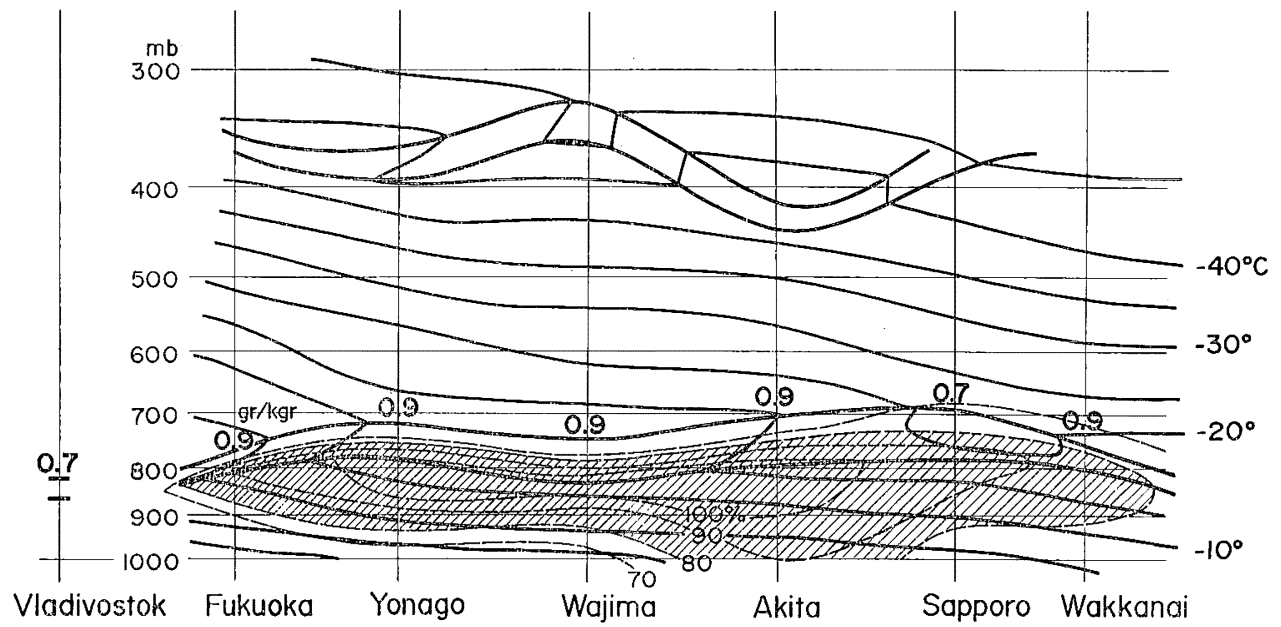

Fig. 5. Same as in Fig. 3, but along the Japan Sea coastal line.

are transferred upward by convection. The cumulus convection does not penetrate the inversion layer which developed over the continent. The large-scale descending motion of the air mass also prevents the modification from reaching a higher level. Thus a uniform mixing ratio is expected in the subsiding polar air mass above the inversion.

Lastly, the time variation of the height of inversion base is to be considered briefly. The relation between the height of the inversion base and the static stability $\partial 0 / \partial p$ in the layer from $1000 \mathrm{mb}$ to $500 \mathrm{mb}$ obtained during the 7 days from Jan. 14

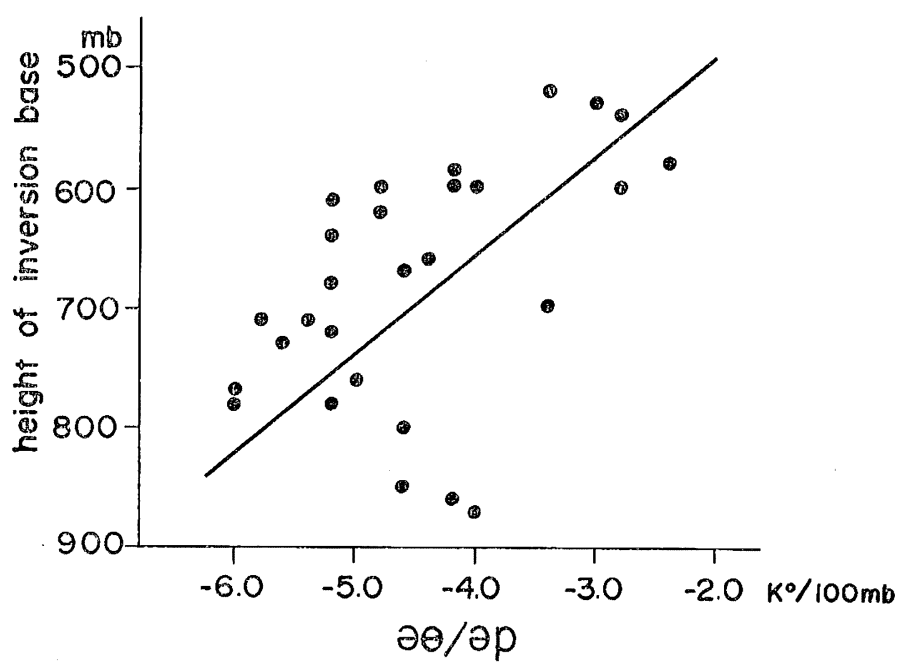

Fig. 6. The relation between the height of the inversion base and the static stability $\partial \theta / \partial p$ in the layer from $1000 \mathrm{mb}$ to $500 \mathrm{mb}$ obtained during the 7 days' period from Jan. 14 to Jan. 21, 1965. 
to Jan. 21, 1965 at Wajima is presented in Fig. 6. The figure shows that the inversion rises when the static stability decreases. This occurs when a cut-off cold vortex passes over the Japan Sea (Matsumoto et al, 1965, Matsumoto and Ninomiya, 1965). This fact leads us to infer that the variation of the inversion height is related to the activity of the cumulus convection which is governed by the synoptic situation, i.e., the vertical stability of the air mass.

\section{Detailed analysis of the structure of the inversion layer and the cumulus con- vection in the sub-inversion layer}

The features of the inversion layer are to be discussed in detail in this section by using the data of radar, dropsonde and aerial photographic observation of cloud.

During the observation flight from Niigata to Toyama via Ryotsu (see Fig. 10), the records of four dropsondes were obtained. The vertical cross section along the flight path is shown in Fig. 7. (The positioning of the observation point is made by the A.D.F. equipped on the aircraft). As the error in humidity measurement by dropsonde is considered to be large, only the temperature field is analysed. The undulation of the inversion layer is observed in this narrow area. The difference of the inversion height is about $500 \mathrm{~m}$ within the distance of $100 \mathrm{~km}$. A similar mesoscale undulation was recognised on Jan. 26 and Jan. 27, 1964 over the same area (Matsumoto and NakAgakI, 1965). This fact is to be discussed in connection with the cumulus convection in the sub-inversion layer.

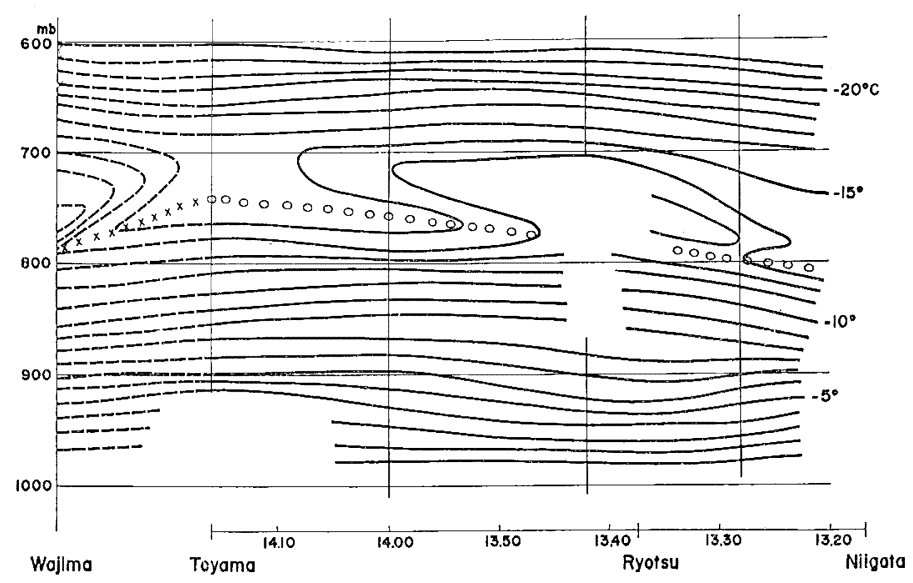

Fig. 7. The vertical cross section along the flight path. The positions on which dropsonde observation is made are shown by vertical lines. The inversion base is shown by small circles. (The radiosonde observation at Wajima at 15 L.M.T. is also shown in the figure).

By applying the principle of triangulation to the successive cloud photographs which are taken at every $30 \mathrm{sec}$ interval, the height of the cloud top is calculated. The lateral extent of analysable area on the high oblique photographs is practically about $40 \mathrm{~km}$ from the flight path. The height of the cloud top thus obtained is pre- 


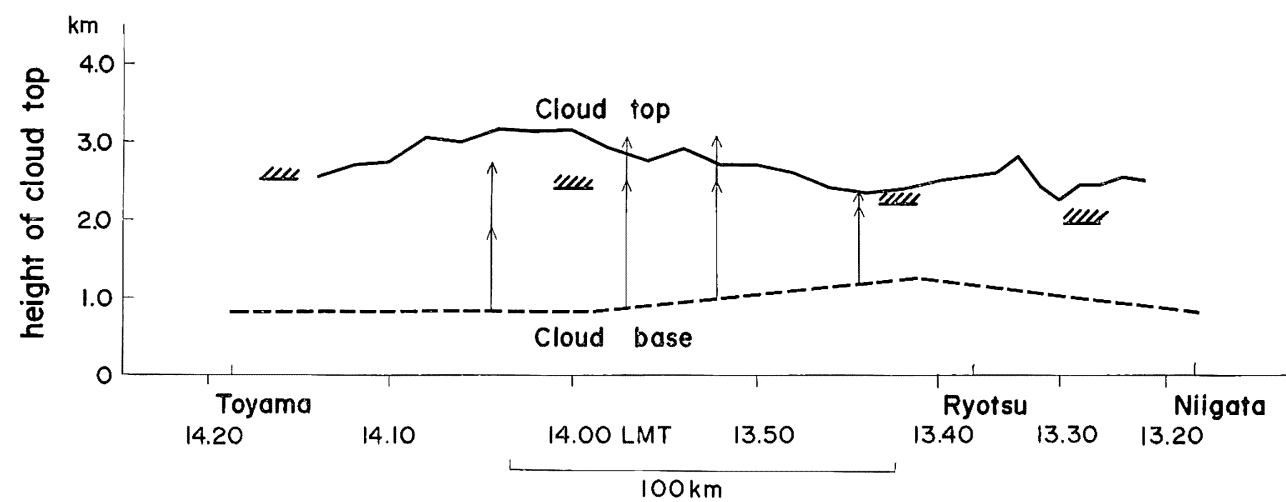

Fig. 8. The height of the cloud top calculated by using aerial photographic data and the cloud base estimated at surface synoptic stations along the flight pass are shown by the heavy solid line and the broken line respectively. The inversion base and the height of radar echoes are also shown by hatches and arrows respectively.

sented in Fig. 8. The height of the inversion base decided by the dropsonde observation and the cloud base observation at the surface synoptic stations are also shown in the figure. The P.P.I. observations by Mt. Yahiko Radar are available for this case study and the estimated heights of radar echoes are also shown by arrows in Fig. 8. Although there is some discrepancy among the three estimations mentioned above, it is clearly recognized that a lower inversion base is observed where the cloud top is lower.

The cloud photographs taken at 13.51, 13.55, 13.59 and 14.04 LMT Jan. 30 are presented in Fig. 9. The coordinate on each frame is the perspective grid for the average cloud height of $2.5 \mathrm{~km}$. The cloud top is very flat in this case as seen in Fig. 9 and no towering cumulus is seen during the flight. A sketch of the radar echoes and their movements is presented in Fig. 10. The local surface weather map at 12 LMT is also shown in Fig. 11. Although no distinct band structure is found in this case, it is notable that the interval between echo groups is about $20-30 \mathrm{~km}$, which is known as the characteristic distance between winter time cumulus bands over the Japan Sea (Asai 1966, Ninomiya 1966). Groups of echoes are also detected on the cloud photographs. Somewhat swelling cumuli are observed on the cloud photographs taken by the left-side camera at 13.55, 13.59 and 14.04 LMT (Fig. 9). As the ground speed of the aircraft is about $4.5 \mathrm{~km}$ per minute, the distance between the cumulus groups is know to be about $25 \mathrm{~km}$. These groups of swelling cumuli are consider as the echo groups $\mathrm{B}, \mathrm{C}$ and $\mathrm{D}$ which are shown in Fig. 10.

The results of analysis mentioned above would suggest that the mesoscale undulation of the inversion layer is related to the distribution of the cumulus groups.

\section{Some discussions on the long-wave radiation balance related to the inversion layer and the momentum mixing in the sub-inversion layer}

The long-wave radiation balance in the lowermost layers of the troposphere will be discussed with reference to the maintenance mechanism of the inversion layer.

Several researches on the air mass modification have been made by applying the 

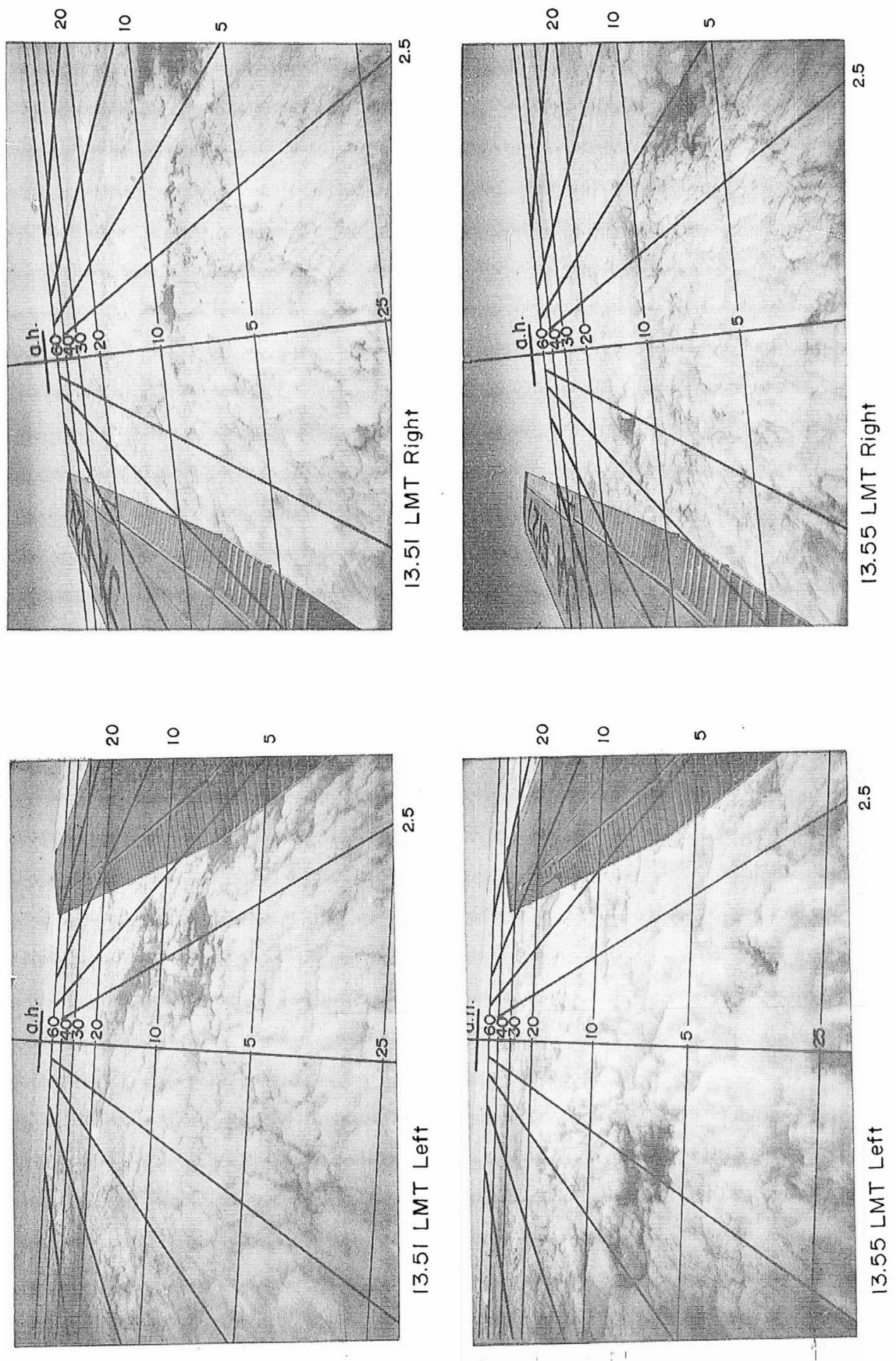

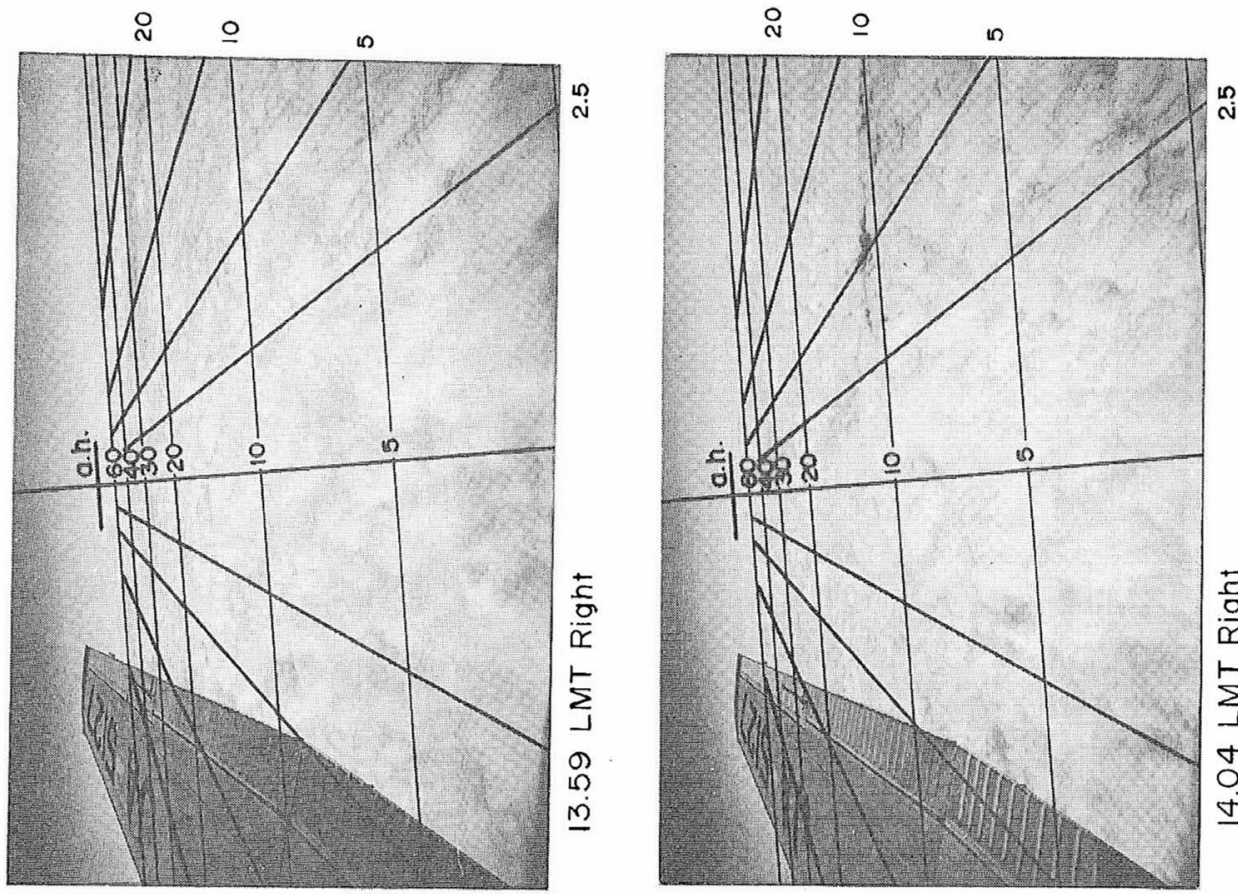

$\stackrel{\Xi}{*}$

เి

हิ

离

+ H.

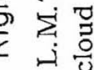

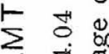

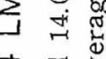

ナ ש

ษ

बึ่

10

ल
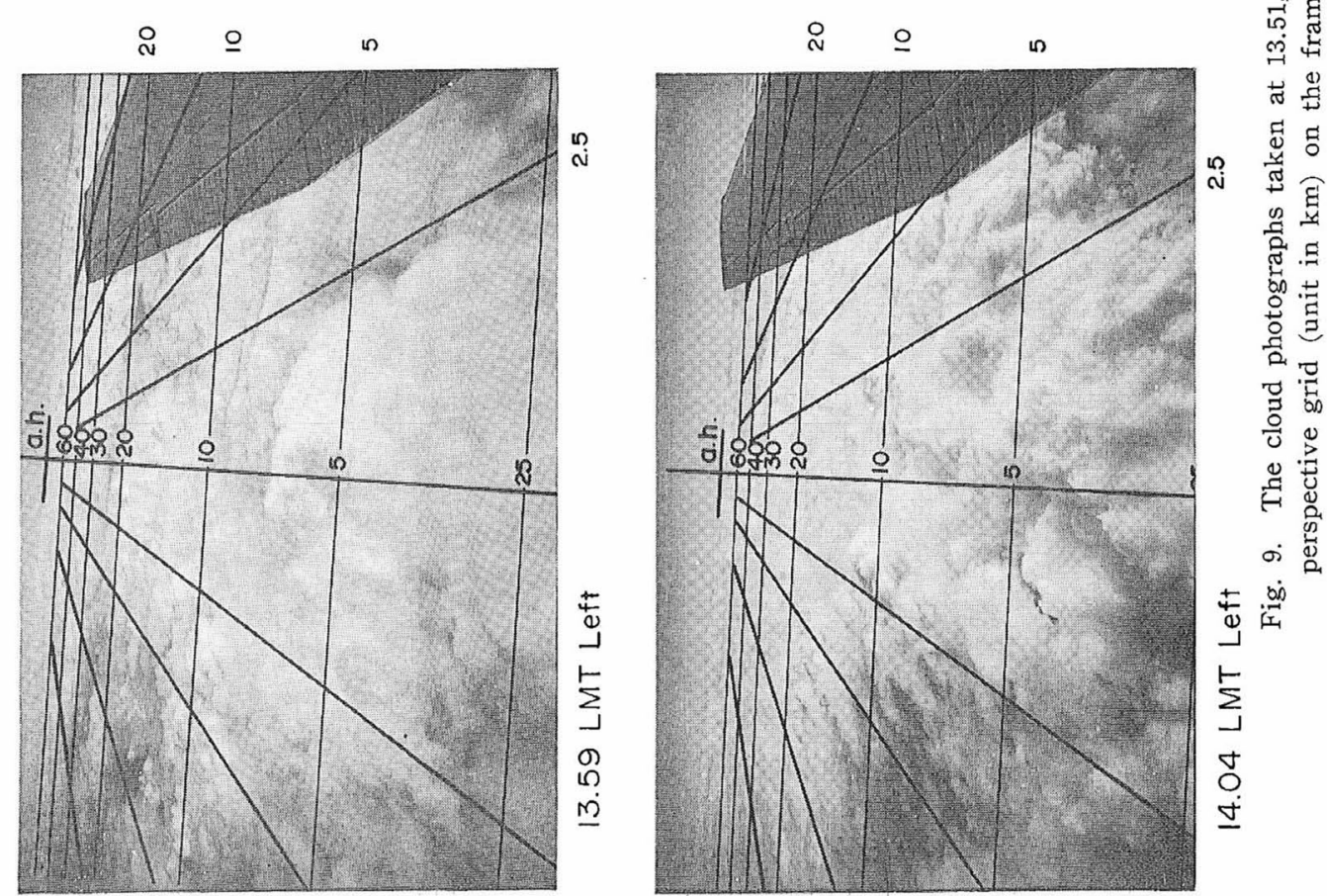
theory of heat conduction (TAKAHASHI 1940, Burke 1945). As a result of the numerical experiment of air mass modification by diffusion process, AsaI (1965) showed that the inversion layer which exists over the polar continent does not disappear perfectly during the air mass passage over the Japan Sea.

Since the radiation, like diffusion, is considered to make the temperature field uniform, the problem why the strong gradient of humidity and temperature in the inversion layer are maintained or even intensified while the polar air travels southeastwards is very difficult to answer. Several investigations show that relative warming due to the radiation occurs at the inversion base (e.g. Staley and Kuhn, 1961).

The recent work by STALEy (1965) showed that the inversion layer is maintained or intensified by the radiation process when a strong vertical gradient of mixing ratio exists. The

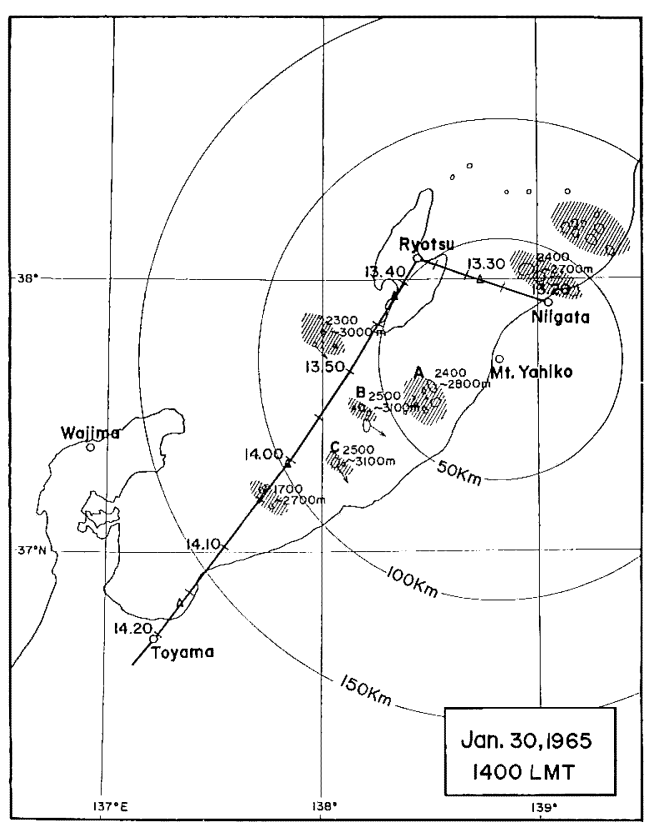

Fig. 10. The distribution of radar echoes. The main echo groups are indicated by hatches. The arrows mean the displacement of echo in 15 minutes. The triangular symbols and the figures along the flight path are the releasing point of the drop-sonde and the time.

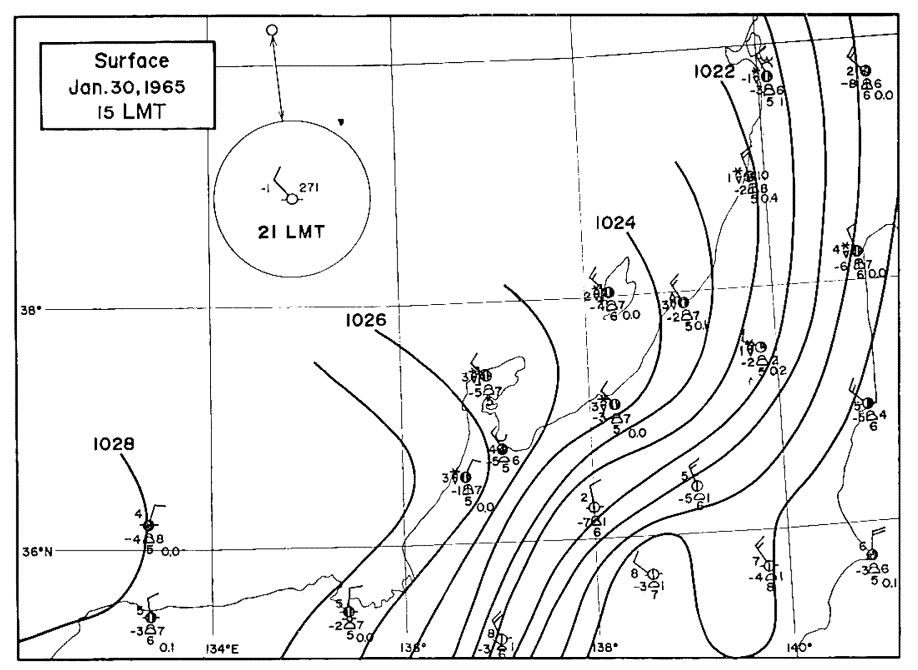

Fig. 11. The local surface weather map at 15 L.M.T., Jan. 30, 1965. 
decrease of the humidity in our case is not so remarkable as in the case treated by STALEY, and thus the existence of a cloud layer would be a more important factor in the consideration of radiative process.

The long-wave radiation balance of the air column at Wajima and Fukuoka is calculated by using the radiation chart (see Fig. 12). As mentioned in section 2, humidity observation at temperatures below $-10^{\circ} \mathrm{C}$ is liable to error, the result at Fukuoka would be more accurate. It is seen from Fig. 12 that remarkable cooling in the cloud layer and very small cooling in the sub-cloud layer and inversion layer are expected. This means that the temperature difference between the cloud top (i.e. the inversion base) and the inversion top is enlarged by the long-wave radiation.

Wajima Jan. 30, 196515 LMT
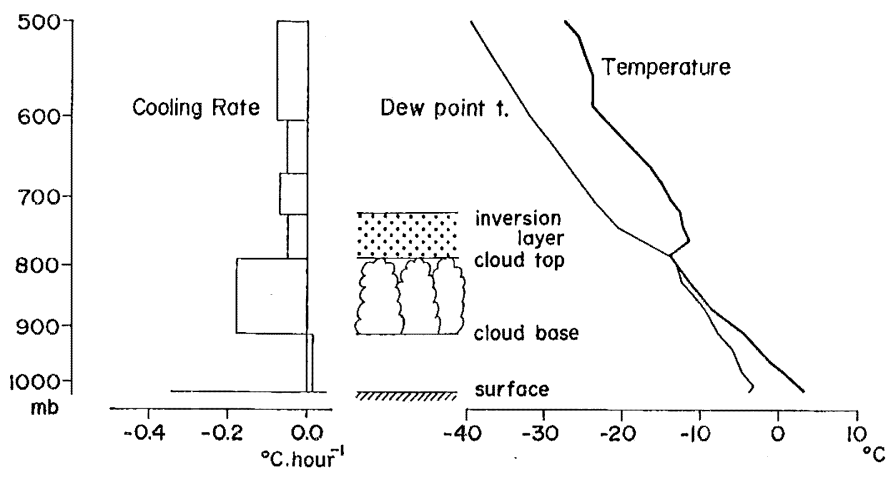

Fukuoka Jan. 30, 196509 LMT

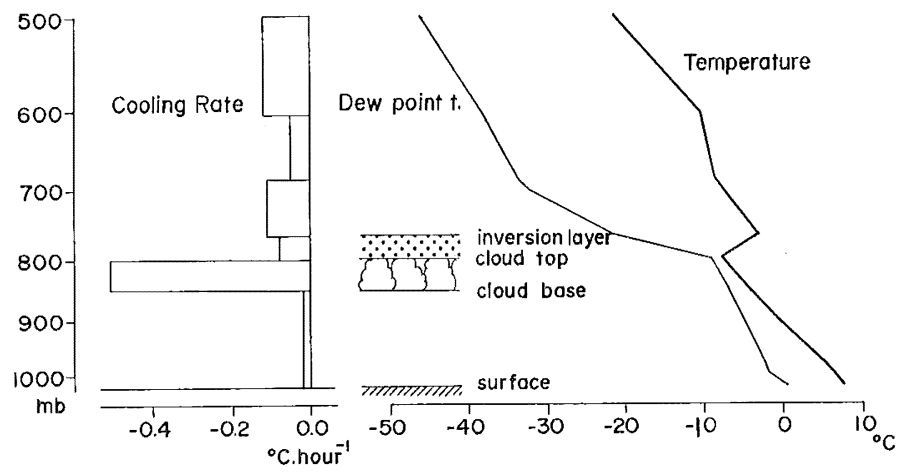

Fig. 12. The vertical distribution of the amount of long wave radiative cooling over Wajima and Fukuoka estimated at 15 and 09 L.M.T. Jan. 30, 1965 respectively.

Thus, it could be said about the maintenance of the inversion as follows. There exists a thick inversion over the polar continent in winter. When the air mass outflows over a relatively warm sea surface, the modification begins in the lower layers. Then the modification rises gradually upward by convective activity. Once clouds are generated, the radiative cooling at the cloud top works to intensify the inversion, which in turn serves as a lid to convection. 
Next, the convective mixing in the sub-inversion layer is to be discussed. In section 2, we pointed out that the equivalent potential temperature is fairy homogeneous in the convective layer. It is also expected that the momentum mixing due to the convective motion would make the wind speed uniform in the sub-inversion layer. The observation shows, as is given in Fig. 13, that the speculation mentioned above holds, at least qualitatively, i.e., a remarkably uniform wind speed is observed in the sub-inversion layer. This uniformity is well noted by comparing it with the mean wind profile obtained for the ten days' period from Jan. 26 to Feb. 5, 1965. At the present time, no information is available on the momentum transfer across the inversion layer nor do we have any knowledge on the mixing process. The quantitative discussion of this problem will be left for the future.

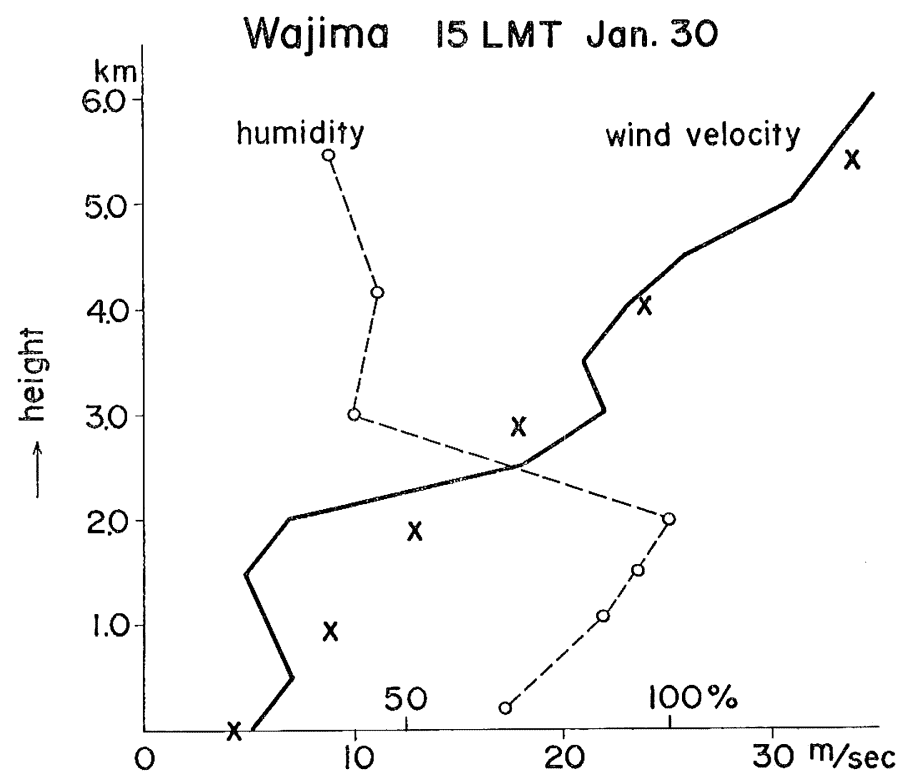

Fig. 13. Vertical distributions of humidity and wind velocity at Wajima at 15 L.M.T., Jan. 30, 1965. The cross symbols show the average wind profile during the 10 days' period from Jan. 26 to Feb. 5, 1965.

\section{Concluding remarks}

The results of the analysis on the aspects of the inversion layer and the cumulus convection in a winter monsoon situation over the Japan Sea are summarized as follows.

1. A remarkable inversion layer develops in the polar air mass when the air mass breaks out over the Japan Sea.

2. The cumulus convection, which is caused by the supply of heat and moisture from the underlying sea surface, is limited in the sub-inversion layer; and very dry air is observed above the inversion. 
3. The height of the inversion base is determined by the activity of cumulus convection which is controlled by the static stability of the air mass.

4. A mesoscale undulation of the inversion layer is observed. The difference of the inversion height is about $500 \mathrm{~m}$ within the distance of $100 \mathrm{~km}$. This undulation is closely related to the cumulus convection, i.e., where a group of active cumuli is observed, a rise in the inversion takes place.

5. Long-wave radiative cooling on the cloud top works to intensify the temperature gradient in the inversion layer.

6. A notably uniform wind speed is observed in the sub-inversion layer. It would be due to the momentum mixing in the sub-inversion layer by the convective motion.

Acknowledgment_- The authors express their thanks to Dr. K. TAKAHAsH for his encouragement and to the members of the Heavy Snow Storm Research Group for discussing, planning and participating in the observation.

\section{References}

Agemarsu, K., 1940: Airplane observation over the Japan Sea, Koku-kisho-hokoku, 3, 202-250.

ArakaWA, H. et al, 1939: Radiosonde observation of winter monsoon made at Toyama, Kokukisho-hokoku, 2, 158-205.

Asal, T., 1965: A numerical study of the air-mass transformation over the Japan Sea in winter. Jour. Met. Soc. Japan, 43, 1-15.

_ 1966: Cloud bands over the Japan Sea off the Hokuriku district during a cold air outburst. Papers in Meteor. and Geophys., 16, 179-194.

Bunker, A. et al, 1949: Vertical distribution of temperature and humidity over the Caribbean Sea. Papers Phys. Oceanog. Met., Mass. Inst. Tech. and Woods Hole Oceanog. Inst., $11,82 \mathrm{pp}$.

BuRkE, C. J., 1945: Transformation of polar continental air to polar maritime air. J. Meteor. 2, 94-112.

MaLkus, J. S., 1958: On the structure of the trade-wind moist layer. Papers Phys. Oceanog. Met., Mass. Inst. Tech. and Woods Hole Oceanog. Inst., 13, 47 pp.

Matsumoto, S. et al, 1963: A note on the mechanism of cold air outbreak. Papers in Meteor. and Geophys., 14, 82-92.

- 1965: Behavior of the extraordinary cold vortex over the Far East coastal area observed during the period from 22 Jan. to 24, Jan. 1963. Journ. Met. Soc. Japan, 43, $100-115$.

Matsumoto, S. and K. NaKagaki, 1965 : Results of dropsonde observation. Tenki, 12, 7-12.

Matsumoto, S. and K. Ninomiya, 1965: An aerophotographic observation of convective clouds in the vicinity of a cold dome center. Journ. Met. Soc. Japan, 43, 218-230.

1966: Some aspects of the cloud formation and its relation to the heat and moisture supply from the Japan Sea surface under a weak monsoon situation. Journ. Met. Soc. Japan, 44, 60-75.

MrYazaWA, S., 1949: Analysis of the winter monsoon by using aerological data (I). Journ. Meteor. Research, 1, 287-291.

Ninomixa, K., 1966: Some aspects of the cloud formation and the airmass modification over the Japan Sea in winter revealed by TIROS observation. Papers in Meteor. and Geophys., 16, 157-178. 
RisH, H. et al, 1951: The north-east trade of the Pacific Ocean. Q. J. Roy. Met. Soc., 77, 598-626.

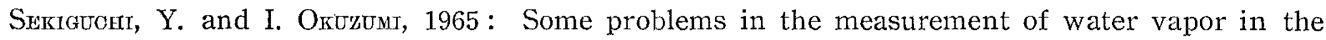
troposphere and stratosphere. Tenki, 12, 274-277.

Stauex, D. O. and P. M. KuEN. 1961: Measurements of radiative cooling through two intense baroclinic zones in the middle troposphere. J. Meteor. 61, 208-215.

Staley, D. O., 1965 : Radiative cooling in the vicinity of inversions and the tropopause. Q. J. Roy. Met. Soc., 91, 282-301.

TAKAHASH, K., 1940: On the transformation of the cold and dry air mass by traveling over warm sea. J. Meteor. Soc. Japan, 18, 77-80.

\title{
ドロップ・ゾンデおよび雲の航空写真観測資料による
}

\section{冬期季節風下の日本海上に発達する逆転層の解析}

\author{
松本誠一・二宮洸三
}

1965 年 1 月 30 日, 寒気吹出の気象状態のもとで, 日本海上飞执いて刘流圈下層飞典型的な逆転層がみ いだされた。この日と行われた，ドロップゾンデ観測，雲の航空写真観測などを含む，北陸索雪特別钼测 の資料をもらいて，この逆転層扔よびその下で発達する積雲対流の様相の詳細を解析した。その結果は次 の様偠約される。

1. 大陸性極気団が寒気の吹出として日本海上飞流れ出す時, 顕著な逆転層が寒気内に見出される。

2. 逝転層以下では，海面からの補給によって積雲対流が活発である。これらの積雲は道転層飞さえぎ られ，逆転層下面より上層では湿度が急激飞減少する。しかも逆転層上面での混合比は日本海域全体にわ たってほぼ一様であって，気団变質が逆轱層上空には拈よんでいない事を示していた。

3. 逆転層下面の高さは，寒気の重直安定度によって支配される積雲対流の強されよって变動している 事，すなわら上層寒気の侵入時飞高い逆転層のあらわれる事が示された。

4. メソスケールの逆転層の起伏が見出された。その起伏は水平距離 $100 \mathrm{~km}$ 飞対し $500 \mathrm{~m}$ の程度で ある。近転層の盛上りは活発な積雲対流の group の上空で見出され，この事はメソスケールの積雲の分 布が近転層の起伏飞関係する事を示している。

5. 長波輻射飞よる雲層上面の冷却は，逝転層を強化・維持するセンス作用する事がわかった。

6. 逆転層下面から海面飞至る大気下層では，相当温位・風速ともに非常に一様である。これ怡転層

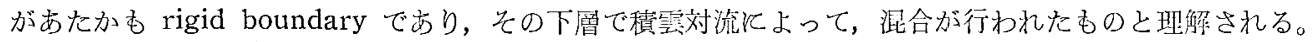
本研究は谷像研究所北陸豪雪特別研究の一部分をなすものである。 